DOI: 10.12731/2658-6649-2020-12-1-48-55

UDC 638.2

\title{
HEREDITARY VARIABILITY OF BIOLOGICAL FEATURES OF MULBERRY SILKWORM UNDER DIFFERENT CONDITIONS
}

\section{Mirzaeva Arzu Rafail gizi}

For the study, mulberry silk was used for different feeding seasons (spring, summer, autumn) and adverse environmental conditions (high temperature, low humidity, poor quality feed) using Atlas-1 and Atlas-2 lines.

During the study, we calculated the selection and genetic parameters (selection variance (SD), genetic growth $(R)$ and realized heritability ( $h 2 R$ ) ratios) of the leading adaptive selection traits in successive generations of the Atlas-1 and Atlas-2 lines.

As a result, compared to the line control population, the Atlas 1 line had a higher rate than the Atlas 2 line for the selection variance. Genetic growth was higher in F7 and F8 than the F6 lineage of the Atlas 1 line. The satin 2 line was the lowest in $F 7$ and the highest in F7 and F8 generations.

The biological parameters of both lines have a high barometric mass due to the hereditary coefficient, the barrel curtain mass is moderate, and the survival barrel silence is even lower.

Generally, both lines have the ability to be inherited by biological indicators. The results from our selection experiments confirmed our theoretical provisions and made it clear that adaptive breeding carried out under pessimistic feeding of all generations would be beneficial.

Keywords: Mulberry silk: hybrid; environmental factors; seasonal feeding; heritability; biological symptoms.

\section{НАСЛЕДСТВЕННАЯ ИЗМЕНЧИВОСТЬ БИОЛОГИЧЕСКИХ ПРИЗНАКОВ ТУТОВОГО ШЕЛКОПРЯДА В РАЗНЫХ УСЛОВИЯХ}

\section{Мирзаева Арзу Рафаил кызы}

Исследование проводилось в различные периоды кормления (весна, лето, осень) и основывалось на неблагоприятные условия окружающей среды (высокая температура, низкая влажность, низкое качество корма) с использованием линий тутового шелкопряда Атлаз-1 и Атлаз-2. 
В ходе исследования были выполнены расчеты ведущих признаков адаптивного отбора, селекиионных и генетических параметров (селекичинных дифференциалов (SD), генетического воспроизводства (R) и реализованной наследственности (h2R)) в последовательных поколениях линий Атлаз-1 и Атлаз-2.

В результате, по сравнению с контрольной популяцией линии, линия Атлаз-1 имела более высокую скорость, чем линия Атлаз-2.для дисперсии выбора. Генетический рост был выше у $F 7$ и F8, чем у линии F6 линии Атлаз-1. Линия Атлаз-2 была самой низкой в F7 и самой высокой в поколениях $F 7$ и F8.

Биологические параметры обеих линий по коэффициенту наследственности были; масса живого кокона высокая, масса вуали кокона средняя, шелковистость живого кокона низкая, даже опускается до минусового показателя.

Как правило, обе линии обладают способностью наследоваться по биологическим показателям. Результаты наших селекиионных экспериментов подтвердили предложенные нами теоретические положения и дали понять, что адаптивное разведение, путем вскармливания всех поколений в пессимистических условиях, будет полезным.

Ключевые слова: тутовый шелкопряд; гибрид; факторы экологической среды; сезонное питание; наследственность; биологический признак.

\section{Introduction}

Creation of breeds and hybrids adapted to climatic conditions, high-yielding and high-quality, local gene-pool and common commercial breeds and hybrids with global breeding intentions is important for our state today.

In modern agricultural animals breeding and intercultural duplication is used mainly as a traditional method. As a result, it is considered to be an effective method for the breeding of animal species. In modern agricultural animals breeding and intercultural duplication is used mainly as a traditional method. As a result, it is considered to be an effective method for the breeding of animal species.

The development of a new organism that results from a combination of two different sexes is accelerated, enhanced, and more productive, also called heterozygosity. In silkworm, heterozygous force and hybridization are widely used. Even silk is one of the most commonly used industries, which have grown from hybridization to extensive manufacturing and industrial scale (Nacheva, Tzenov, Petkov, 2004).

Increasing the productivity of mulberry silkworm breeds is achieved by breeders in the process of their selection, mainly by selection for biological features and sometimes for technological reasons. It is known that the selection effect directly depends on the value of the genetic parameter called the heri- 
tability factor. However, this genetic parameter is not a constant quantity that remains constant. Changing the feeding conditions of the parent and offspring of mulberry silkworm's results in a change in the value of this genetic parameter, which in turn cause a change in the selection effect. It is worth noting that the impact of feeding on parents and offspring of mulberry silkworm on the hereditary coefficient of quantitative traits of mulberry silkworms, including biological ones, is one of the few issues that have been studied. For example, in Uzbekistan, the first study on the inheritance ratios for the control population based on our literature data began in the 70 s of the last century on the inherited economic quantities of mulberry silkworms in the former Soviet Union. For the first time in the former USSR U. Nasirillayev (Nasirillaev, 1985) and in Azerbaijan under the leadership of U. Nasirillayev B. Abbasov (Abbasov, 2000) studied the hereditary biological characteristics of cocoon.

\section{Methodology and material}

In practice of every three years, in spring, summer, and autumn seasons, from the 1st day of the fourth age until the end of feeding, the temperature in the greenhouse is $28-30^{\circ} \mathrm{C}$ (norm $23-24^{\circ} \mathrm{C}$ ) and relative humidity is $50-55 \%$ (norm 70-75). \%) is kept low. By the age of 1 to 3 years, mulberry silk was fed 6 times a day (7-8 times) and 4 times ( 5 times the norm) during the fourth age.

As for both selection experiments, line selection of the line Atlas- 1 and Atlas-2 started from the 1 st generation and continued through the 8 th generation, and we used "control populations" to determine the genetic effect of the selection (Mirzoeva, Karaev, Seidova, 2018; Stahl, Rush, Schiller, Vahal, 1973; Petkov, Petkov Z., Greiss, 2003).

Generation of offspring was made from unfavorable feeding options in each line, and biological indicators were determined.

On the basis of the numerical material obtained from the experiment, the inheritance coefficients of the biological productive traits of both lines were determined (Table 1-2).

The coefficient of actual inheritance is determined by the following formula (Stahl, Rush, Schiller, Vahal, 1973);

$$
h_{R}^{2}=\frac{R}{S D}=\frac{\overline{y_{1}}-\bar{y}_{0}}{\overline{X_{1}}-\bar{X}_{0}}
$$

- here the actual (real) selective effect of $\mathrm{R}$ activity is the difference between the mean values of the children of the selected and unselected parents $\left(R=\bar{Y}_{1}-\bar{V}_{0}\right)$;

Difference in $S D$ between the selection variance or the mean of the selected parent group and population $\left(S D=\bar{X}_{1}-\bar{X}_{0}\right)$; 
In our analysis, we are guided by the following genetic clauses: It is known that the genetic effect of selection for any quantitative trait $(R)$, that is, the genetic increase in trait in the offspring, is the average phenotypic value of the offspring (Range). The genetic increase in trait in the offspring should be equal to the difference in the average phenotypic value $\left(X_{p a r}\right)$ of the offspring $\left(X_{p a r}\right)$ in the offspring, which is mathematically expressed by $R=X_{o f f s}-X_{p a r}$ formula (Kenzhaev, 1981; Nasirillaev, 1985).

Our researchers have often conducted this experiment from F1 to F5. However, since many hybrids have lost their heterozygosity after the F5 generation, we have passed our experiment from F5 to F8, since the generation of mulberry silk breeds is expected to produce at least 9-12 generations which causes some indicators to change.

Results of the study: From our experience we can say the same.

First, the heritability of the biological traits of mulberry silkworms is adversely affected by environmental deterioration, including deterioration of feed quality.

Second, the reduction of hereditary ratios is more strongly influenced by the nutritional conditions of the parents and offspring, and in the summer and autumn compared with the spring.

Third, the heritability of the biological trait depends on the degree of tolerance to adverse environmental conditions of the breed or hybrid that is attributed to the various environmental factors, including the quality of the feed.

We used the "control population" method to accurately determine the genetic effect of the sampling on both lines.

Table 1.

Leading selection symptoms in successive generations of the Atlas-1 line selection and genetic parameters. (selection differentials, genetic growth and realized heritability ratios)

\begin{tabular}{|c|c|c|c|c|c|c|c|}
\hline \multirow{2}{*}{$\begin{array}{c}\text { Signs of } \\
\text { selection }\end{array}$} & \multicolumn{3}{|c|}{ The parents' generation } & \multicolumn{3}{c|}{ The offspring } & \multirow{2}{*}{$\mathrm{h}^{2} \mathrm{R}$} \\
\cline { 2 - 8 } & $\mathrm{X}_{\mathrm{pop}}$ & $\mathrm{X}_{\mathrm{ch}}$ & $\mathrm{SD}$ & $\mathrm{X}_{\mathrm{GNP}}$ & $\mathrm{X}_{\mathrm{SP}}$ & $\mathrm{R}$ & \\
\hline & \multicolumn{3}{|c|}{$\mathrm{F}_{5}$} & \multicolumn{3}{|c|}{$\mathrm{F}_{6}$} & \\
\hline DBK & 1,86 & 1,98 & 0,12 & 2,07 & 2,15 & 0,08 & 0,666 \\
\hline BPK & 441 & 475 & 34 & 462 & 478 & 16 & 0,470 \\
\hline DBI & 23,73 & 24,00 & 0,27 & 22,39 & 22,22 & $-0,17$ & $-0,629$ \\
\hline \multicolumn{7}{|c|}{$\mathrm{F}_{6}$} \\
\hline DBK & 2,15 & 2,35 & 0,20 & 1,86 & 2,02 & 0,16 & 0,800 \\
\hline BPK & 478 & 525 & 47 & 440 & 470 & 30 & 0,800 \\
\hline DBI & 22,22 & 22,34 & 0,31 & 23,30 & 23,30 & 0,10 & 0,322 \\
\hline & \multicolumn{3}{|c|}{$\mathrm{F}_{7}$} & \multicolumn{5}{c|}{$\mathrm{F}_{8}$} & \\
\hline
\end{tabular}


End of the Table 1 .

\begin{tabular}{|c|c|c|c|c|c|c|c|}
\hline DBK & 2,02 & 2,15 & 0,13 & 1,87 & 2,04 & 0,07 & 0,538 \\
\hline BPK & 470 & 510 & 40 & 433 & 458 & 25 & 0,626 \\
\hline DBI் & 23,30 & 23,73 & 0,43 & 23,17 & 22,40 & 0,23 & 0,534 \\
\hline
\end{tabular}

DBK-age cocoon weight, BPK-barrel curtain mass, DBI-age cocoon silk.

Leading selection symptoms in successive generations of the Atlas-2 line selection and genetic parameters. (selection differentials, genetic) growth and realized heritability ratios)

\begin{tabular}{|c|c|c|c|c|c|c|c|}
\hline \multirow{2}{*}{$\begin{array}{l}\text { Signs of } \\
\text { selection }\end{array}$} & \multicolumn{3}{|c|}{ The parents' generation } & \multicolumn{3}{|c|}{ The offspring } & \multirow{2}{*}{$h^{2} R$} \\
\hline & $\mathrm{X}_{\mathrm{pop}}$ & $\mathrm{X}_{\mathrm{ch}}$ & $\mathrm{SD}$ & $\mathrm{X}_{\mathrm{GNP}}$ & $\mathrm{X}_{\mathrm{SP}}$ & $\mathrm{R}$ & \\
\hline & \multicolumn{3}{|c|}{$\mathrm{F}_{5}$} & \multicolumn{3}{|c|}{$\mathrm{F}_{6}$} & \\
\hline DBK & 1,86 & 1,95 & 0,06 & 2,12 & 2,12 & 0,00 & 0,600 \\
\hline BPK & 432 & 465 & 18 & 492 & 480 & -10 & $-0,555$ \\
\hline \multirow[t]{2}{*}{ DBİ } & 23,22 & 23,84 & 0,18 & 22,73 & 22,60 & $-0,13$ & $-0,07$ \\
\hline & \multicolumn{3}{|c|}{$\mathrm{F}_{6}$} & \multicolumn{3}{|c|}{$\mathrm{F}_{7}$} & \\
\hline DBK & 2,12 & 2,27 & 0,15 & 1,95 & 2,06 & 0,11 & 0,733 \\
\hline BPK & 480 & 525 & 45 & 456 & 490 & 34 & 0,755 \\
\hline \multirow[t]{2}{*}{ DBİ } & 22,60 & 23,12 & 0,52 & 23,43 & 23,78 & 0,35 & 0,670 \\
\hline & \multicolumn{3}{|c|}{$\mathrm{F}_{7}$} & \multicolumn{3}{|c|}{$\mathrm{F}_{8}$} & \\
\hline DBK & 2,06 & 2,22 & 0,16 & 1,98 & 2,09 & 0,11 & 0,687 \\
\hline BPK & 490 & 500 & 10 & 463 & 468 & 5 & 0,500 \\
\hline DBİ & 23,78 & 22,52 & $-1,26$ & 23,41 & 22,30 & $-1,11$ & $-0,880$ \\
\hline
\end{tabular}

DBK-age cocoon weight, BPK-barrel curtain mass, DBI-age cocoon silk.

From the data, it is clear from the data that the selection of lines Atlas- 1 and Atlas- 2 over the 5th generation, the differential selection bar weighs 0.12 and $0.06 \mathrm{~g}$ per barrel mass, 34 and $18 \mathrm{mg}$ per barrel mass, and $0.27 \%$ and $0.18 \%$ respectively. As it can be seen, the biological signs of the Atlas-1 line are, to some degree, higher than that of the Atlas-2 line. Selection differentials obtained from the 6 th generation selection of lines Atlas- 1 and Atlas- 2 are 0.20 and $0.15 \mathrm{~g}$ for the mass of the live cocoon, 47 and $45 \mathrm{mg}$ for the barrel mass, and $0 \%$ for the silica silk density. , 31 and $0.52 \%$ respectively. As it can be seen, the biological signs of the Atlas-1 line are higher than the selection bias mass of the Atlas-2 line, while the Atlas- 2 line is higher for the Atlas- 1 line. In the latter generation, it is clear that in the 7th generation, the differential selection of the lines Atlaz-1 and Atlaz-2 was 0.13 and $0.16 \mathrm{~g}$, respectively, for the mass of the barrel, 40 and $10 \mathrm{mg}$ for the barometric mass, and the silica of the live bar. 0.43 and $-1.26 \%$. 
As it can be seen, the biological signs of the Atlas-1 line are, to some degree, higher or lower than that of the Atlas-2 line. Even with the selection differential, the silica of the living bar decreased by $1.26 \%$.

Under the influence of the selection of Atlas 1 line on the 5th generation, the 6th generation of the cocoon is $0.08 \mathrm{~g}$ for the average mass of the live cocoon, $16 \mathrm{mg}$ for the average barrel curtain, and $0.17 \%$ for the cocoon silk. Atlas $2 \mathrm{did}$ not increase with the average mass of the live cocoon, the average mass of the barrel curtain was $10 \mathrm{mg}$, and the genetic barrel was $0.13 \%$. Under the influence of the sampling of the 6th generation of Atlas-1 lines, the 7th generation of lines had a genetic increase of $0.16 \mathrm{~g}$ per barrel average weight, $30 \mathrm{~mm}$ per barrel average mass, and $0.10 \%$ for live barrel silk. There was an absolute genetic increase in saturation of line 2 satellites by $0.11 \mathrm{~g}$ to the average mass of the cocoon, to $34 \mathrm{mg}$ per barrel mass, and to $0.35 \%$ for the survival of silica. Under the influence of the sampling of the 7th generation of satin-1 lines, the average mass of the live cocoon in the 8 th generation of the lines is $0.07 \mathrm{~g}$, the average mass of the barrel is $25 \mathrm{mg}$, the live barrel silk is $0.23 \%$, the thickness of the barrel is $0 \%$. There was a genetic increase of $11 \mathrm{~g}$, the average mass of the barrel curtain was $5 \mathrm{mg}$, and the silkworm was $1.11 \%$.

The data in Table 1-2 show that in the 6th generation of the Atlas- 1 line, the hereditary coefficient was $0.666 \mathrm{~g}$ according to the mass of the live cocoon, $0.470 \mathrm{mg}$ for the barrel mass, and $0.629 \%$ for the live barrel silk. Atlas 2 , there was an increase of $0.600 \mathrm{~kg}$ per cocoon mass, a decrease of $0.55 \mathrm{mg}$ per barrel mass, and a reduction of $-0.007 \%$ for silica barrel. In the 6th generation of both lines, we observed a legacy of succession. In the 7th generation of the Atlas-1 line, the hereditary coefficient was $0.800 \mathrm{~g}$ for the mass of the live cocoon, $0.800 \mathrm{mg}$ for the barrel curtain mass, and $0.322 \%$ for the cocoon silk mass. Atlas 2 was $0.733 \mathrm{~g}$ for the mass of the live cocoon, $0.755 \mathrm{mg}$ per barrel mass, and $0.670 \%$ for the cocoon silica. In the 8 th generation of the Atlas- 1 line, the hereditary coefficient was $0.538 \mathrm{~g}$ for the mass of the live cocoon, $0.625 \mathrm{mg}$ for the barrel mass, and $0.534 \%$ for the cocoon silk. In Atlas 2, there was a decrease of $0.677 \mathrm{~kg}$ by the mass of the live cocoon, $0.500 \mathrm{mg}$ by the mass of the barrel curtain, and by $0.880 \%$ on the silica of the live cocoon.

\section{Result}

There are enough lines for both lines to pass through their biological characteristics. The Atlas 1 line had higher performance. Based on the results of our experience, we propose that the creation of new breeds (reducing the feed rate, increasing the temperature in the greenhouse, reducing relative humidity, etc.) to feed in unfavorable conditions. In this case, biological characteristics of the descendants of individ- 
uals selected during the spring and spring-autumn seasons of the next generation, in particular, the inheritance coefficients of the leading selection trait will remain quite high, but the cost of changing the selection as a result of selection increases with phenotypic variability of biological traits in adverse conditions.

As a result, the genetic effect of selection on all seasons will increase significantly and be fully realized. This will reduce the cost of creating new breeds and improving existing breeds and reduce costs for the process.

Thus, how artificially unfavorable it is during the seasons, due to changes in the content of mulberry leaves, and whether the heat is too high or too hot during the seasons increases the phenotypic variability of all biological traits.

\section{References}

1. Abbasov B.G. Selektsionno-geneticheskie parametry khozyaystvenno-poleznykh priznakov rayonirovannykh porod tutovogo shelkopryada Azad $i$ Gyandzha 1 [Selection and genetic parameters of economically useful traits of the regional silkworm breeds Azad and Ganja 1]. Kirovobad, 1975, pp. 81-91.

2. Abbasov B.Kh. Izuchenie ekologicheskoy ustoychivosti porod i gibridov tutovogo shelkopryada otnositel'no obshchey produktivnosti kokona [Cotton production of silk fabric relative to the overall productivity of the cocoon]. Baku, 2000. XV, pp. 49-55.

3. Kenzhaev B. Nasleduemost'khozyaystvenno-tsennykh priznakov tutovogo shelkopryada $v$ razlichnykh usloviyakh vykormki [Inheritance of economically valuable mulberry silkworms in various feeding conditions]. Tashkent, 1981. $24 \mathrm{p}$.

4. Mirzoeva A.R., Karaev V.Kh., Seidova G.A. Agrarnaya Nauka Azerbaydzhana. 2018, №5, pp. 119-121.

5. Nasirillaev U.N. Geneticheskie osnovy otbora tutovogo shelko-pryada [Genetic basis for the selection of silkworm]. Tashkent: Fan, 1985. 60 p.

6. Shtal' V., Rash D., Shiller R., Vakhal Ya. Populyatsionnaya genetika dlya zhivotnovodov-selektsionerov [Population genetics for livestock breeders]. M.: Kolos, 1973, $439 \mathrm{p}$.

7. Nacheva Y., Tzenov P., Petkov N. Study on the heterosis and its components in hybrids between monobivoltine and polyvoltine strains of silkworm (Bombyx mori L.) with reference to the weigth characteristic. Bulgarian J. of Agric. Sci., 2004, N 6, pp. 741-744.

8. Petkov N., Petkov Z., Greiss H. Manifestation of heterosis and inheritance of productive characters in simple and complex silkworm Bombyx mori L. hybrid combinations II. Shell weigth and shell ratio. Bulgarian J. of Agric. Sci., 2003, V. 9. N 3, pp. 385-389. 


\section{Сиисок литературы}

1. Аббасов Б.Г. Селекционно-генетические параметры хозяйственно-полезных признаков районированных пород тутового шелкопряда Азад и Гянджа 1: дис. ... канд. биол. наук. Кировобад, 1975. С. 81-91.

2. Аббасов Б.Х. Изучение экологической устойчивости пород и гибридов тутового шелкопряда относительно общей продуктивности кокона. Баку, 2000. XV. C. 49-55.

3. Кенжаев Б. Наследуемость хозяйственно-ценных признаков тутового шелкопряда в различных условиях выкормки: Автореф. дис..канд.с.-х.наук, Ташкент, 1981. 24 p.

4. Мирзоева А.Р., Караев В.Х., Сеидова Г.А. Изучение воздействия факторов экологической среды на гибриды тутового шелкопряда // Аграрная Наука Азербайджана. 2018, №5. С. 119-121.

5. Насириллаев У.Н. Генетические основы отбора тутового шелкопряда. Ташкент: Фан, 1985. 60 с.

6. Шталь В., Раш Д., Шиллер Р., Вахал Я. Популяционная генетика для животноводов-селекционеров. М.: Колос, 1973, 439 с.

7. Nacheva Y., Tzenov P., Petkov N. Study on the heterosis and its components in hybrids between monobivoltine and polyvoltine strains of silkworm (Bombyx mori L.) with reference to the weigth characteristic // Bulgarian J. of Agric. Sci., 2004, N 6, pp. 741-744.

8. Petkov N., Petkov Z., Greiss H. Manifestation of heterosis and inheritance of productive characters in simple and complex silkworm Bombyx mori L. hybrid combinations II. Shell weigth and shell ratio // Bulgarian J. of Agric. Sci., 2003, V. 9. N 3, pp. 385-389.

\section{DATA ABOUT THE AUTHOR}

Mirzaeva Arzu Rafail gizi, scientific worker

Institute of Genetic Resources of Azerbaijan National Academy of Sciences, Department of Genetic Resources of Agricultural Animals 155, Azadlig Ave., Baku, AZ 1106, Azerbaijan mirzyevaa@bk.ru

\section{ДАННЫЕ ОБ АВТОРЕ}

Мирзаева Арзу Рафаил кызы, научный сотрудник

Институт Генетических Ресурсов Национальной Академии Наук Азербайджана, Отдел генетических ресурсов сельскохозяйственных животных

nр. Азадльг 155, г. Баку, AZ 1106, Азербайджан

mirzyevaa@bk.ru 